\title{
Website e-Commerce Penjualan Sepatu Sekolah Studi Kasus : Toko Sepatu Nadin di Tembilahan
}

\section{Dwi Yuli Prasetyo}

\author{
Program Studi Sistem Informasi, Universitas Islam Indragiri \\ Jln.Provinsi Parit1 Tembilahan - Indragiri Hilir - Riau \\ Email : dwiyuliprasetyo@gmail.com
}

\begin{abstract}
The rapid development of technology makes users increasingly spoiled by their presence, especially those that are developing today, namely e-commerce websites, especially with the spread of the Covid-19 virus pandemic that occurs almost everywhere around the world, making people very afraid to interact outside the home, with e-commerce makes buyers or consumers very easy in the process of purchasing transactions. Consumers do not need to come to the Nadin Tembilahan shoe store but they only need to open an e-commerce website using either a handphone or a computer, buyers can choose and buy the desired shoes. Nadin shop is one of the shops that operates in the shoe sales department in the area of tembilahan, managing a shoe shop is not as easy as imagined. Lack of sales in the days of the Covid-19 pendemic and the difficulty of processing payments and shipping goods, making a decrease in sales turnover shoes. Another problem faced by Nadin shoe stores is one of them is the process of selling shoes that still use the manual system, not yet done using e-commerce websites. Many weaknesses and omissions such as slow sales services, stacking shoes, inaccurate and timely reporting. With this problem the researchers tried to help to design a shoe sales e-commerce website, with the presence of this e-commerce very helpful for shop owners in managing their shoe stores, this proved to easily convey the promotion of shoes to the public, purchase transactions, payment and shipping of goods, because the buyer does not have to come to the shop, the buyer just simply makes a purchase transaction and waits for his shoes to come home. The presence of this e-commerce website really helped Nadin shopkeepers in Tembilahan in running their business and also provided a decent profit especially during the Covid-19 virus pandemic.
\end{abstract}

Keywords: website, e-commerce, shoes, tembilahan, covid

\begin{abstract}
Abstrak
Majunya perkembangan teknologi membuat pengguna semakin dimanjakan dengan kehadirannya terutama yang lagi berkembang saat ini yaitu website e-commerce, apalagi dengan semakin merebaknya pandemi virus Covid-19 yang terjadi hampir melanda diseluruh dunia, membuat masyarakat sangat takut untuk berinteraksi diluar rumah, dengan adanya website e-commerce membuat pembeli atau konsumen sangat dimudahkan dalam proses transaksi pembelian. Konsumen tidak perlu datang ke toko sepatu Nadin Tembilahan namun mereka hanya perlu membuka website e-commerce baik menggunakan handphone ataupun komputer, pembeli bisa memilih dan membeli sepatu yang diinginkan. Toko Nadin merupakan salah satu toko yang bergerak pada bagian penjualan sepatu di wilayah tembilahan, mengelola toko sepatu tidaklah semudah yang dibayangkan. Sepinya penjualan dimasa pendemi Covid-19 ini dan susahnya proses pembayaran serta pengiriman barang, membuat menurunnya omset penjualan sepatu. Permasalahan lain yang dihadapi oleh toko sepatu nadin salah satunya adalah masalah proses penjualan sepatu yang masih menggunakan sistem manual, belum dilakukan menggunakan website e-commerce. Banyak kelemahan dan kelalaian seperti lambatnya pelayanan penjualan, penumpukan sepatu, penyajian laporan yang tidak akurat dan tidak tepat waktu. Dengan adanya masalah tersebut peneliti mencoba membantu untuk merancang website e-commerce penjualan sepatu, dengan hadirnya e-commerce ini sangat membantu pemilik toko dalam mengelola toko sepatunya hal ini terbukti dengan mudahnya menyampikan promosi sepatu ke masyarakat, transaksi pembelian, pembayaran dan pengiriman barang, karena pembeli tidak harus datang ketoko, pembeli hanya cukup melakukan transaksi pembelian dan menunggu sepatunya datang kerumah. Dengan hadirnya website ecommerce ini sangat membantu pemilik toko Nadin di tembilahan dalam menjalankan usahanya dan juga memberikan keuntungan yang lumayan apalagi disaat pandemi virus Covid-19.

Katakunci: website, e-commerce, sepatu, tembilahan, covid
\end{abstract}




\section{PENDAHULUAN}

Sistem dapat didefinisikan dengan pendekatan prosedur dan dengan pendekatan komponen. Dengan pendekatan prosedur, sistem dapat didefiniskan sebagai kumpulan dari prosedur-prosedur yang mempunyai tujuan tertentu. Dengan pendekatan komponen, sistem dapat didefiniikan sebagai kumpulan dari komponen yang saling berhubugan satu dengan yang lainnya membentuk satu kestuan untuk mencapai tujuan tertentu. Informasi merupakan data yang telah dioalah dan diatur ulang menjdi suatu bentuk yang lebih berarti dn ditujukan untuk seseorang. Informasi dibentuk dari kombinasi data, yang diharapkan memiliki arti bagi yang menerimanya Informasi merupakan hasil keluaran dari sistem informasi. Informasi yang berguna memiliki karakteristik sebagai berikut (1) akurat, (2) tepat waktu, (3) lengkap, (4) ringkas. Sistem informasi merupakan gabungan dari manusia, perangkat keras, perangkat luna, jaringan telekomunikasi, dan sumber data yang engumpulkan, mengubah dan menyebarkan informasi dalam sebuah organisasi sehingga dapat mendukung perusahaan, pekerjaan, pelanggan, rekan kerja, serta supplie, gambaran sebaran informasi terlihat pada Gambar 1 (Ginting, 2013).

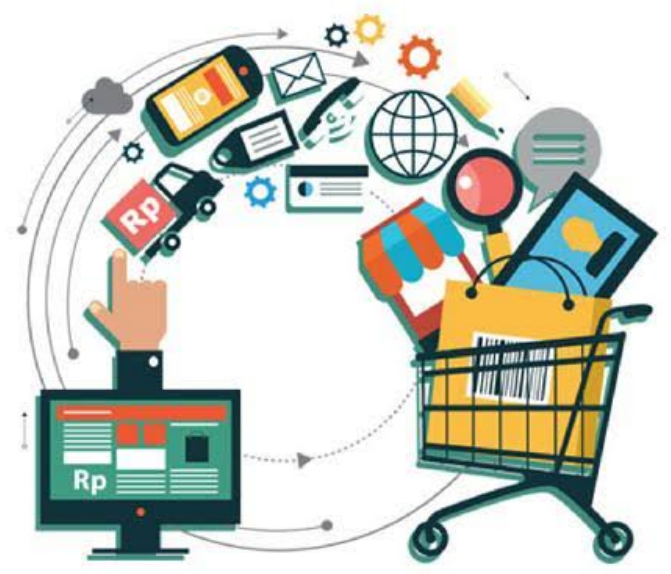

Gambar 1. Gambaran Sebaran Informasi

Mengolah data menjadi bentuk yang lebih berguna dan lebih berarti bagi penerimanya yang menghasilkan informasi. Siklus informasi atau siklus pengolahan data dapat dilihat pada Gambar 2 (Arista, dkk, 2014).

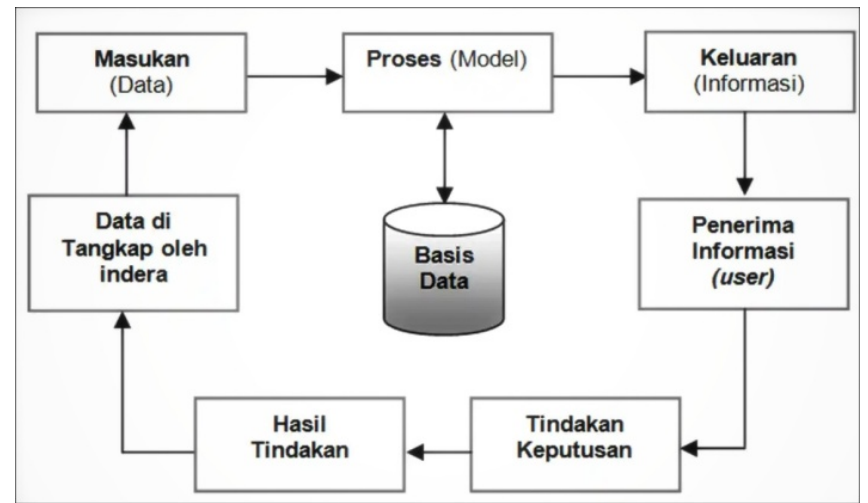

Gambar 2. Siklus Informasi

John Burch dan Gary Grudnitski mengemukakan bahwa sistem informasi terdri dari komponen-kompoen yang disebutnya dengan istilah blok bangunan (building block), yaitu block masukan (input block), blok model (model block), blok keluaran (output block), blok teknologi (technology block), bok basis data (database block) dan blok kendali (control block) (Ika Mariska, 2015).

E-Commerce adalah sebuah bentuk transaksi yang berhubungan dengan aktivitas komersial, baik itu organisasi maupun individual yang berdasarkan pengolahan dan transmisi data yang terdigitalisasi, termasuk teks, suara dan gambar visual. Pada umumnya E-Commerce mengacu pada aplikasi perdagangan yang menggunakan media internet untuk melakukan transaksi online, sperti untuk belanja produk dan jasa. Contohnya terjadi ketika konsumen mengorder, produk berwujud maupun tidak berwujud melalui internet. World Wide Web (WWW), yang lebih dikenal dengan istilah web, merupakan salah satu layanan yang didapat oleh pemakai komputer yang terhubung dengan internet. Dengan menggunakan teknologi hypertext, pemakai web dituntun untuk menemukan informasi dengan mengikuti link-link yang disediakan dalam dokumen web yang ditampilkan dalam browser web, gambaran kerja e-Commerce dapat dilihat pada Gambar 3 (Ginting, 2013). 


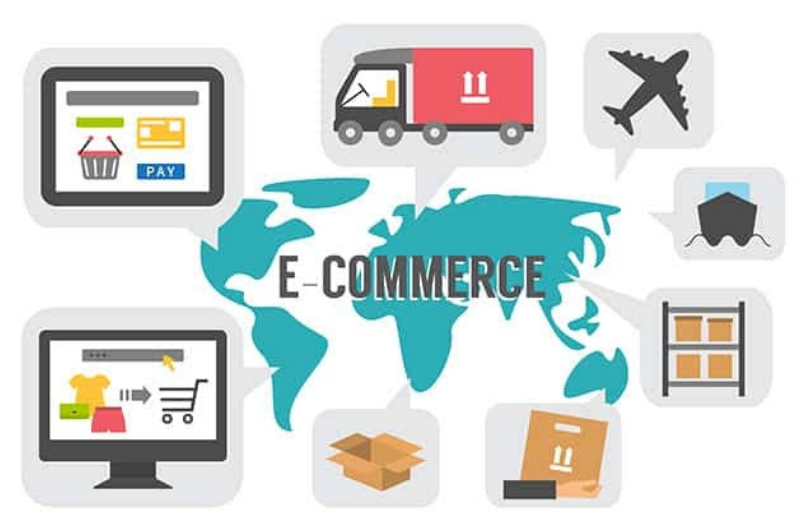

Gambar 3. E-Commerce

Tahun 1993, Tim Banners-Lee dan peneliti lain di European Particle Physics Lab (Consei Europeen pour la Recherche Nucleare, atau $C E R N)$ di Geneva, Swiss, mengembangkan suatu cara untuk menshare data antar koleganya menggunakan sesuatu yang disebut dengan hypertext. Pemakai di CERN dapat menampilkan dokumen pada layar komputer dengan menggunakan software browser baru. Kode-kode disisipkan kedalam dokumen elektronik ini, memungkinkan pemakai untuk meloncat dari suatu dokumen ke dokumen lainnya pada layar dengan hanya memilih sebuah hyperlink. Kemampuan internet dimasukkan kedalam browser ini sehingga dapat loncat dari suatu dokumen ke dokumen lainnya, tidak lagi dari suatu komputer saja, tetapi dapat meloncat ke dokumen lain yang letaknya pada komputer remote (Budiyanto, 2012).

Seorang peneliti dapat juga mengirimkan sebuah file dari komputer remote ke sistem lokalnya, atau log in kedalam suatu sistem remote hanya dengan mengklik hyperlink, tidak perlu melalui mekanisme FTP atau telnet. Jalan pintas CERN digunakan sebagai dasar dari yang disebut sekarang dengan World Wide Web dan berikut server dan browser webnya (sekarang di maintenance oleh World Wide Web Consortium disingkat W3C). W3C ini bertugas untuk membangun standar bagi teknologi web. Pada awal perkembangannya, sewaktu browser masih berbasiskan teks hanya terdapat sekitar 50 website. Di akhir tahun 1995 jumlah ini telah berkembang mencapai sekitar 280.000 website. Dan diperkirakan sekarang ini, jumlah pemakai web telah mencapai sekitar 30 juta pemakai seluruh dunia. Browser web adalah software yang digunakan untuk menampilkan informasi dari server web. Software ini kini telah dikembangkan
JUTI-UNISI (Jurnal Tenik Industri UNISI) dengan menggunakan user interface grafis, sehingga pemakai dapat dengan mudah melakukan 'point' dan 'click' untuk pindah antar dokumen, bentuk gambaran World Wide Web terlihat pada Gambar 4 (Budiyanto, 2012).

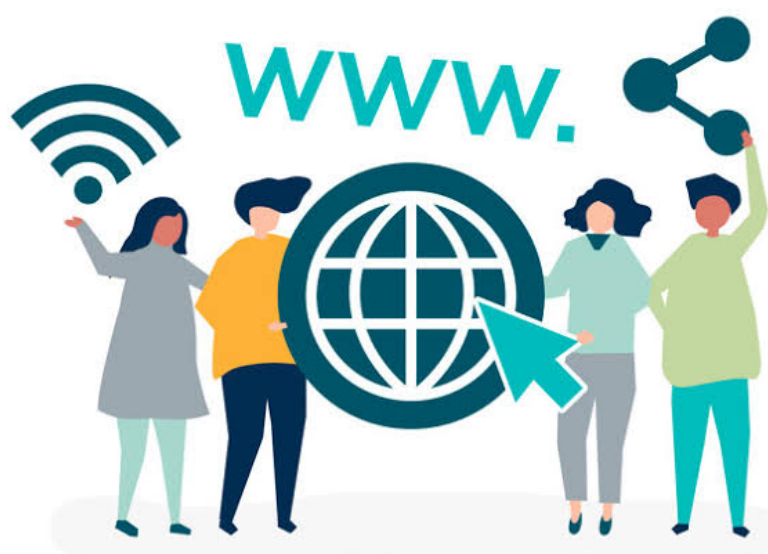

Gambar 4. World Wide Web

Namun perkembangan dari browser mode teks ini tidaklah secepat browser web dengan GUI. Dapat dikatakan saat ini hanya ada 2 browser web GUI yang populer yaitu: Internet Explorer dan Netscape Navigator. Kedua browser ini bersaing untuk merebut pemakainya, dengan berusaha mendekati standar spesifikasi dokumen HTML yang direkomendasikan oleh W3C. Server web adalah komputer yang digunakan untuk menyimpan dokumen-dokumen web, komputer ini akan melayani permintaan dokumen web dari kliennya. Browser web seperti Explorer dan Navigator berkomunikasi melalui jaringan (termasuk jaringan internet) dengan server web, menggunakan HTTP. Browser akan mengirimkan request kepada server untuk meminta dokumen tertentu atau layanan lain yang disediakan oleh server. Server memberikan dokumen atau layanannya jika tersedia juga dengan menggunakan protokol HTTP, gambaran bentuk browser dapat dilihat pada Gambar 5 dan Gambar 6 (Budiyanto, 2012).

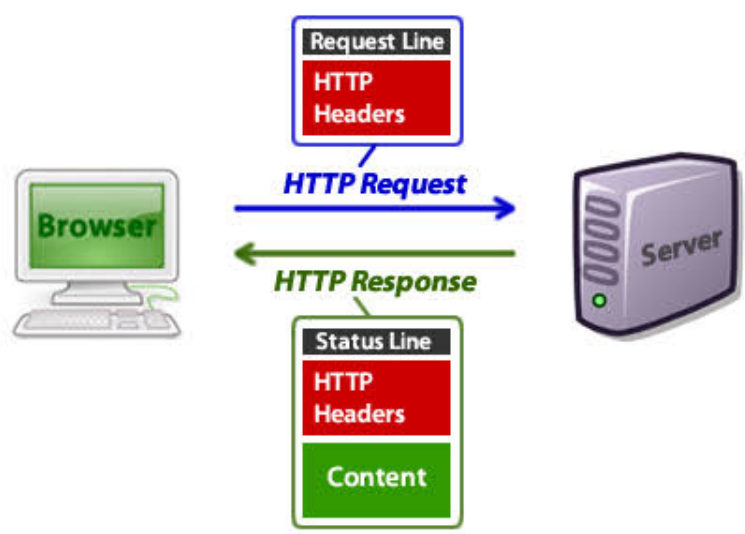

Gambar 5. Browser Http Request Response 


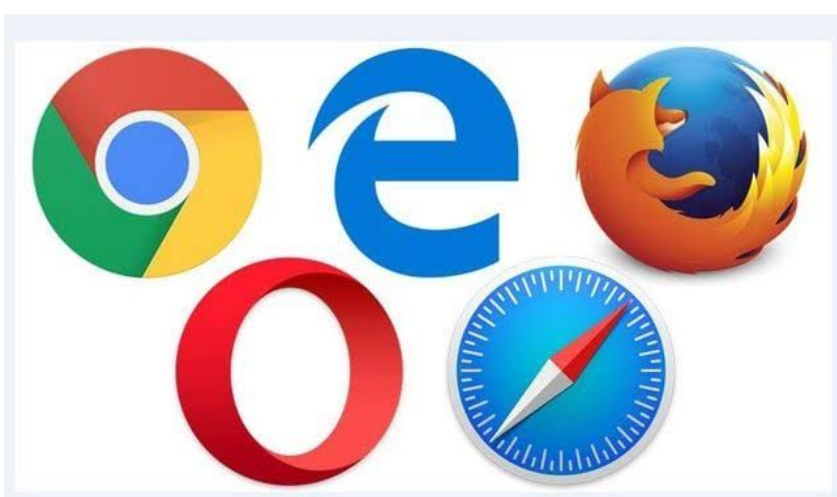

Gambar 6. Software Browser

Sebuah halaman web yang menggunakan HTML saja, hanya mampu menampilkan beberapa gambar dan teks yang statis. Sedangkan data didalamnya tidak dapat berubah-ubah secara dinamis. Disi lain kita memerlukan halaman web yang aktif dan dapat mengakses database. Sebuah halaman web yang aktif akan selalu berubah-ubah tergantung dari isi database ataupun keadaan yang kita buat dalam aplikasi web tersebut. PHP adalah bahasa scripting sisi server (server side) yang dapat disisipkan di HTML (embedded). Dukungan koneksinya hampir kesemua program database seperti MySQL, PostgreSQL, mSQL, dan masih banyak lagi. Proses PHP dilakukan di server sehingga tingkat keamanannya sangat tinggi (Nitra, 2009).

MySQL adalah sebuah perangkat lunak sistem manajemen biasa data SQL (bahasa ingris: database management system) atau BDMS yang multithread, multi-user, dengan sekitar 6 juta instalasi di seluruh dunia. MySQL AB membuat MySQL tersedia sebagai perangkat lunak gratis dibawah lisensi GNU/General Public License (GPL), tetapi mereka juga menjual dibawah lisensi komersial untuk kasus-kasus dimana penggunanya tidak cocok dengan pengguna GPL. Database merupakan media yang digunakan untuk menampung data. Ada beberapa macam database, antara lain Oracle, Microsoft Access, Microsoft $S Q L$ Server, MySQL dan lain-lain. Seperti ini dijelaskan diatas bahwa Joomla diciptakan dengan menggunakan bahasa scripting PHP dan database MySQL maka kita akan menggunakan database ini untuk menampung data-data Joomla milik kita, seperti artikel, user password dan lain-lain, halaman ruang kerja dari $M y S Q L$ terlihat seperti Gambar 7 (Nitra, 2009).

JUTI-UNISI (Jurnal Tenik Industri UNISI)

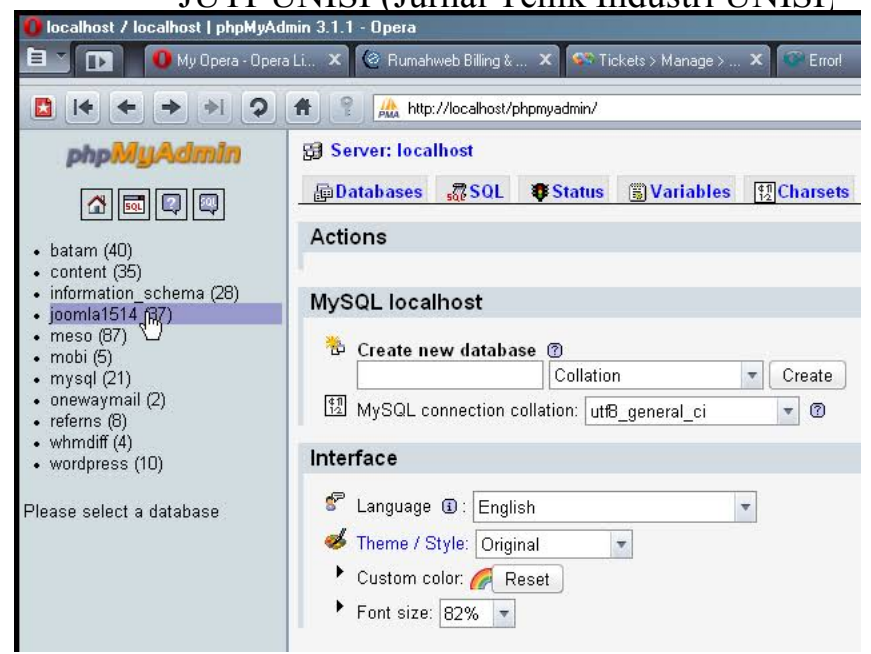

Gambar 7. phpMyAdmin

XAMPP adalah perangkat lunak gratis yang mendukung banyak sistem operasi dan merupakan kompilasi dari beberapa program. Fungsinya adalah sebagai server yang terdiri (localcost), yang terdiri atas program Apache HTTP Server, MySQL database, dan penterjemah bahasa yang ditulis dengan bahasa pemograman PHP dan Perl. Nama XAMPP merupakan singkatan dari X (empat sistem operasi apapun, Apache, MySQL, PHP dan Perl). Program ini tersedia dalam GNU General Public Lisensi dan bebas, merupakan web server yang mudah digunakan yang dapat melayani tampilan halaman web yang dinamis. UML bukanlah suatu proses melainkan bahasa pemodelan secara grafis untuk menspesifikasikan, memvisualisasikan, membangun, dan mendokumentasikan seluruh artifak sistem perangkat lunak, gambaran bentuk XAMPP terlihat pada Gambar 8 (Nitra, 2009).

\section{[8) XAMPP}

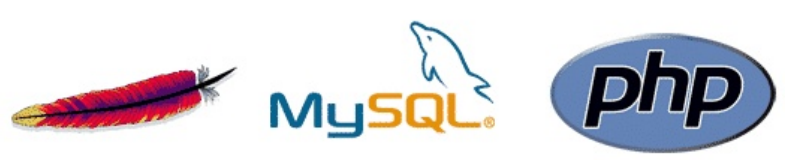

Gambar 8. Software XAMPP

Macromedia Dreamweaver adalah sebuah HTML editor professional untuk mendesain secara visual dan mengelola situs atau halaman web. Versi terbaru dari Macromedia Dreamweaver saat ini adalah Dreamweaver 12, terdapat beberapa kemapuan bukan hanya sebagai software untuk desain web saja, tetapi juga untuk menyunting kode serta pembuatan aplikasi $\mathrm{Web}$ 
Vol.4.No.1 Juni 2020

dengan menggunakan berbagai bahasa pemprograman $W e b$, antara lain JPS, PHP, ASP, dan Cold Fusion, gambaran bentuk software Dreamweaver terlihat pada Gambar 9 (Nitra, 2009).

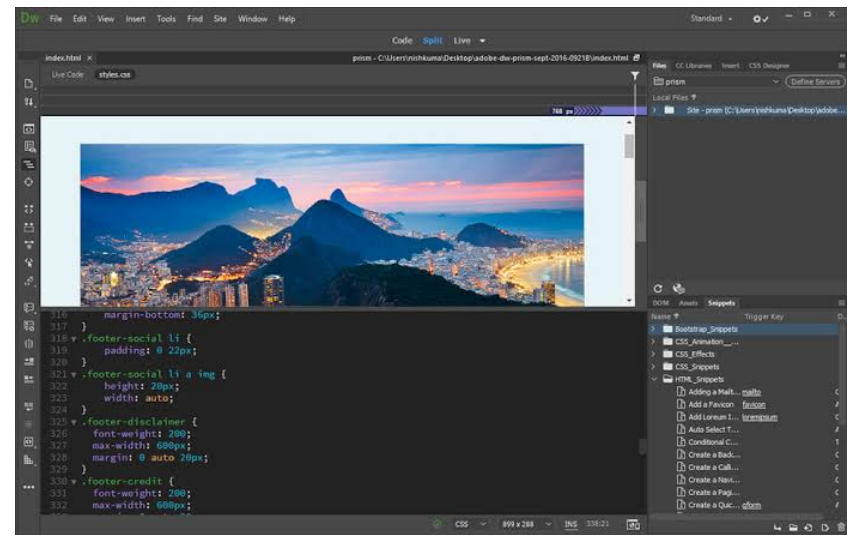

Gambar 9. Software Dreamweaver

\section{METODELOGI PENELITIAN}

Dalam penelitian ini metode penelitian yang dipakai merupakan pembuatan sistem yang dimulai dari pengumpulan informasi, mencari data dilapangan, mencari sumber literatur yang terkait dalam penelitian, menganalisis sistem yang lama, membuat analisis sistem yang baru, perancangan logika sistem, perancangan antarmuka sistem, implementasi program, verifikasi program, perawatan program dan menghasilkan sebuah kesimpulan. Kesemua tahapan penelitian ini terlihat pada Gambar 10

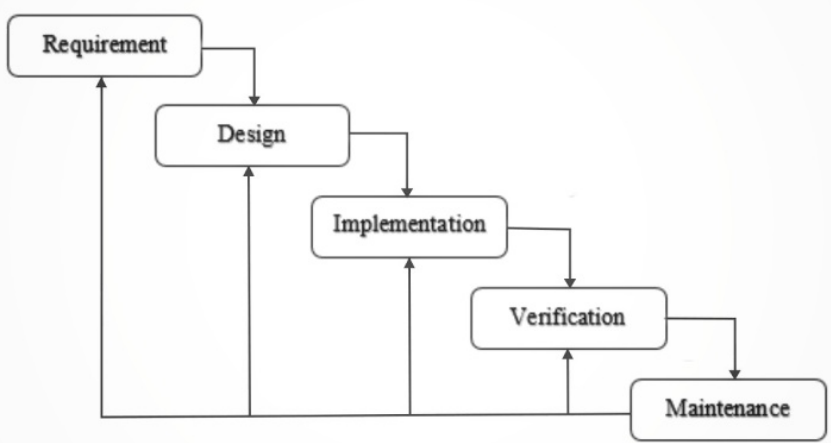

Gambar 10. Metode Waterfall

Metode air terjun atau yang sering disebut metode waterfall sering dinamakan siklus hidup klasik (classic life cycle), dimana hal ini menggambarkan pendekatan yang sistematis dan juga berurutan pada pengembangan perangkat lunak, dimulai dengan spesifikasi kebutuhan pengguna lalu berlanjut melalui tahapan-tahapan perencanaan (planning), permodelan (modeling), konstruksi (construction), serta penyerahan sistem ke para pelanggan/pengguna (deployment), yang
JUTI-UNISI (Jurnal Tenik Industri UNISI) diakhiri dengan dukungan pada perangkat lunak lengkap yang dihasilkan. Tahapan metode waterfall dapat dilihat pada gambar di bawah ini.

Dalam pengembangannya metode waterfall memiliki beberapa tahapan yang berurut yaitu: requirement (analisis kebutuhan), design system (desain sistem), Coding (pengkodean) \& Testing (pengujian), Penerapan Program, pemeliharaan. Tahapan tahapan dari metode waterfall adalah sebagai berikut (1) Requirement Analisis, tahap ini pengembang sistem diperlukan komunikasi yang bertujuan untuk memahami perangkat lunak yang diharapkan oleh pengguna dan batasan perangkat lunak tersebut. Informasi ini biasanya dapat diperoleh melalui wawancara, diskusi atau survei langsung. Informasi dianalisis untuk mendapatkan data yang dibutuhkan oleh pengguna, (2) System Design, spesifikasi kebutuhan dari tahap sebelumnya akan dipelajari dalam fase ini dan desain sistem disiapkan. Desain Sistem membantu dalam menentukan perangkat keras (hardware) dan sistem persyaratan dan juga membantu dalam mendefinisikan arsitektur sistem secara keseluruhan, (3) Implementation, pada tahap ini sistem pertama kali dikembangkan di program kecil yang disebut unit, yang terintegrasi dalam tahap selanjutnya. Setiap unit dikembangkan dan diuji untuk fungsionalitas yang disebut sebagai unit testing, (4) Integration \& Testing, seluruh unit yang dikembangkan dalam tahap implementasi diintegrasikan ke dalam sistem setelah pengujian yang dilakukan masing-masing unit. Setelah integrasi seluruh sistem diuji untuk mengecek setiap kegagalan maupun kesalahan, (5) Operation \& Maintenance, tahap akhir dalam model waterfall. Perangkat lunak yang sudah jadi, dijalankan serta dilakukan pemeliharaan. Pemeliharaan termasuk dalam memperbaiki kesalahan yang tidak ditemukan pada langkah sebelumnya. Perbaikan implementasi unit sistem dan peningkatan jasa sistem sebagai kebutuhan baru (Pressman, 2012).

\section{HASIL DAN PEMBAHASAN}

Sebelum dilakukannya perancangan sebuah sistem, diperlukan adanya suatu gambaran yang memuat keterangan atau informasi yang berhubungan dengan sistem. Hal ini bertujuan agar mempermudah dalam menganalisa dan merancang sistem yang baru. 


\subsection{Diagram Use Case}

Diagram Use Case menjelaskan skenario diagram keseluruhan dari sistem penjualan Sepatu, Pada sistem ini hanya pemilik yang dapat melakukan login, proses selanjutnya pemilik dapat melakukan cek stok barang yang masih tersedia atau kosong, mengelola data konsumen, menginput barang, menginput transaksi penjualan dan membuat laporan perbulan dari penjualan. Sedangkan pada skenario konsumen, konsumen dapat melihat barang yang ingin diorder, proses selanjutnya konsumen dapat melakukan order, jika barang tersedia maka konsumen dapat mengisi data, setelah itu konsumen dapat melakukan transaksi, seperti yang tertera pada Gambar 11

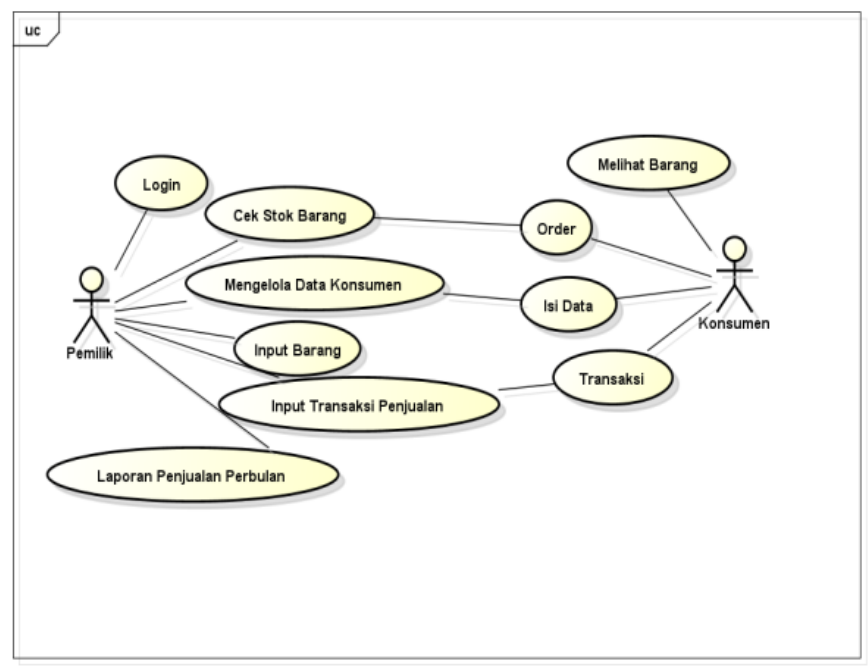

Gambar 11. Diagram Usecase

\subsection{Diagram Activity}

Sistem penjualan Sepatu pada Toko Sepatu Nadin Tembilahan yang dimulai dari star pemilik, pemilik dapat melakukan login dengan menginputkan username dan password, sistem akan memproses untuk, jika gagal maka pemilik bisa login kembali. Setelah itu pemilik melakukan pengecekan terhadap stok yang masih tersedia dan yang kosong. Untuk konsumen yang ingin melakukan order barang, terlebih dahulu konsumen bisa melihat barang yang ingin diorder, setelah barang dipilih konsumen bisa langsung melakukan order, jika stok kosong konsumen dapat melakukan order ulang dan jika stok tersedia konsumen bisa melakukan pengisian data, dan tugas pemilik mengelola data konsumen, setelah itu konsumen dapat melakukan transaksi kepada pemilik. Pada pemilik dapat melakukan penginputan barang / sepatu, selanjutnya pemilik dapat menginput transaksi penjualan dan setelah itu membuat laporan penjualan perbulan pada toko
JUTI-UNISI (Jurnal Tenik Industri UNISI) Sepatu Nadin Tembilahan yang akan diproses melalui sistem, seperti yang terlihat di Gambar 12

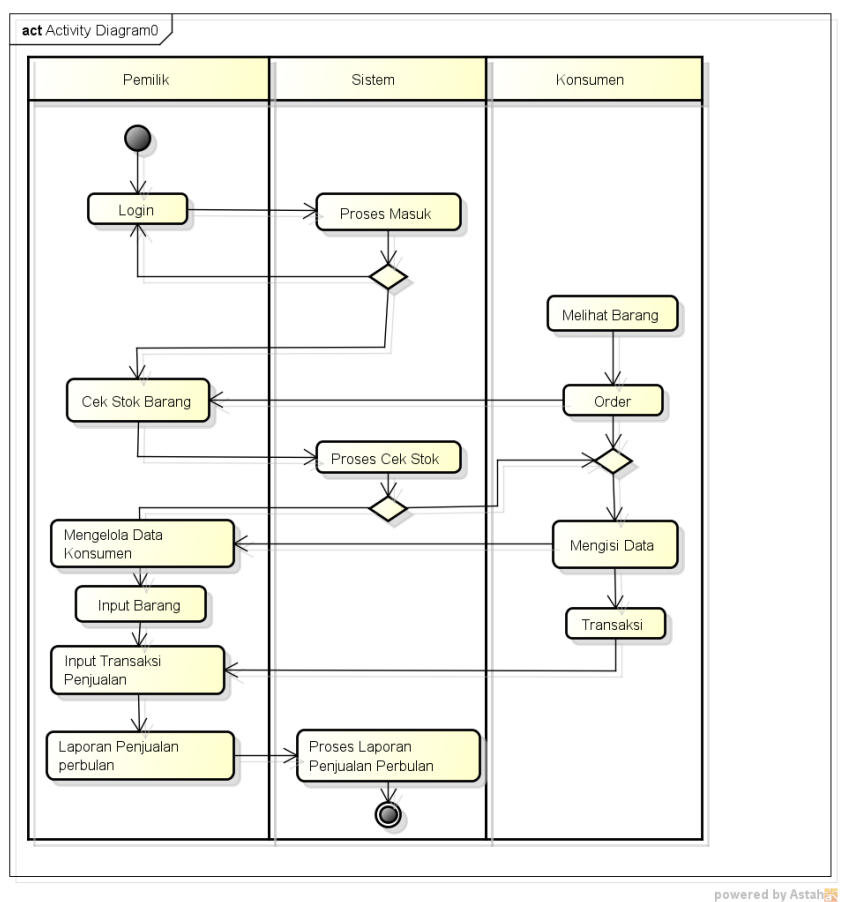

Gambar 12. Diagram Activity

\subsection{Diagram Class}

Diagram class sistem penjualan Toko Sepatu Nadin dimulai dari class pemilik, pemilik melakukan login pada dengan input username dan password, setelah melakukan login pemilik melalukan cek stok terhadap barang yang di order konsumen, sebelum class konsumen melakukan order, konsumen terlebih dahulu mengisi nama, alamat dan no hp konsumen, selanjutnya konsumen melihat barang yang sesuai kebutuhan, selanjutnya konsumen dapat melakukan order, jika produk ada konsumen bisa langsung mengisi data, setelah pengisian data konsumen, data tersebut dikelola oleh class pemilik, setelah itu konsumen melakukan proses transaksi, kembali pada class pemilik yang melakukan proses input barang / Sepatu, setelah itu pemilik melakukan proses input transaksi penjulan, dan proses yang terakhir pemilik membuat laporan penjualan perbulan, seperti yang terlihat di Gambar 13 


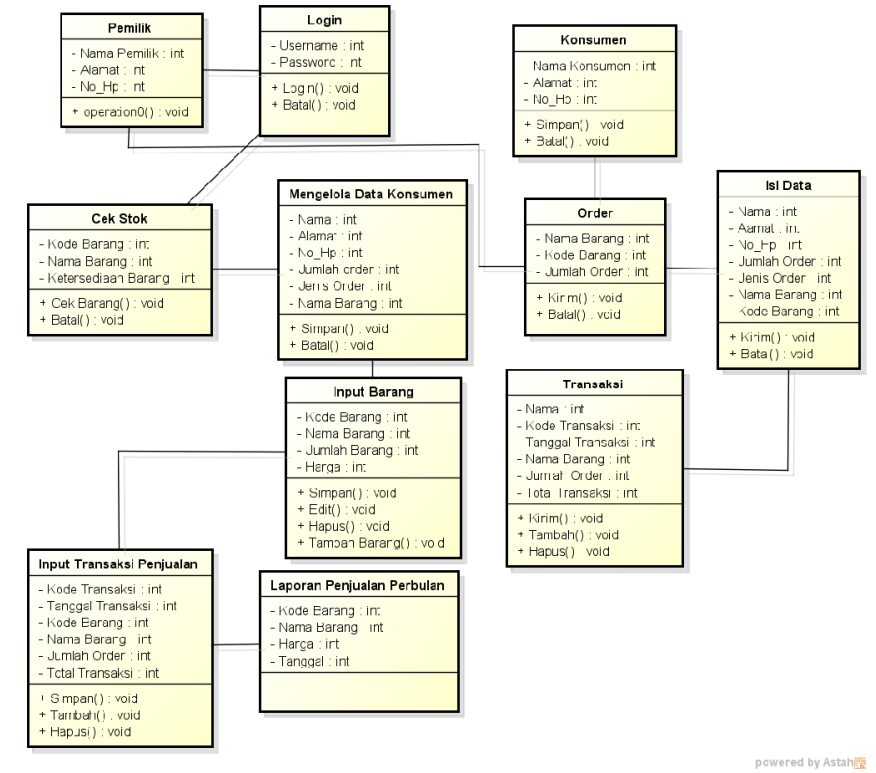

Gambar 13. Diagram Class

\subsection{Analisis PIECES}

Untuk mengidentifikasi masalah perlu dilakukan analisis terhadap kinerja, informasi, ekonomi, pengendalian, efisiensi dan pelayanan terhadap pengguna. Metode analisis ini dikenal dengan analisis PIECES yaitu (performance, information, economy, control, efficiency, service) dari analisis ini terdapat beberapa masalah yang ditemukan, yaitu :

a) Analisis Kinerja (Performance Analysis), penggunaan atau pengoperasian untuk sistem pakar usulan ini tidaklah sulit. Sistem ini dapat dengan mudah digunakan oleh siapa saja. Dengan menggunakan sistem ini maka akan mempermudah kinerja seorang mekanik dalam mengidentikasi jenis kerusakan,

b) Analisis Informasi (Information Analysis), dengan adanya sistem ini dapat mempermudah para pengguna untuk memperoleh informasi yang dibutuhkan dengan mengoperasikan sistem. Informasi yang dihasilkan dijamin akurat berdasarkan akuisisi seorang pakar yang ahli dalam bidangnya,

c) Analisis Ekonomi (Economy Analysis), dengan adanya system ini diharapkan dapat meringankan biaya pengeluaran pengguna untuk melakukan proses konsultasi terhadap mekanik karena dengan menggunakan system ini sudah dapat mengetahui jenis kerusakan dan solusi perbaikan yang tepat,

d) Analisis Pengendalian (Control Analysis), pada sistem ini pengendalian sistem dibuat
JUTI-UNISI (Jurnal Tenik Industri UNISI) untuk melindungi sistem dengan cara pembuatan username pengguna dan password agar lebih aman,

e) Analisis Efesiensi (Effeciency Analysis), dengan adanya website e-Commerce sepatu ini memudahkan konsumen dalam mencari dan membeli sepatu melalui website. Dengan demikian disimpulkan bahwa waktu yang dibutuhkan dapat diminimalkan seefisien mungkin,

f) Analisis Pelayanan (Service Analysis), pada dasarnya pelayanan yang diberikan dengan adanya sistem ini kepada pengguna sudah cukup baik.

\subsection{Implementasi Sistem}

Hasil implementasi website e-Commerce Toko Sepatu Nadin Tembilahan adalah sebagai berikut :

a) Form Login, tampilan antar muka login merupakan halaman yang menampilkan username dan password, halaman login ini digunakan oleh admin untuk masuk pada sebuah program, adapun form login dapat dilihat pada Gambar 14

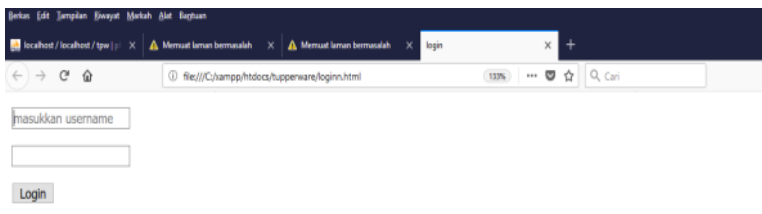

Gambar 14. Form Login

b) Form Menu Utama, Tampilan antar muka halaman utama adalah halaman yang menampilkan halaman seluruh informasi yang ada dalam website e-commerce toko sepatu nadin, mulai dari sepatu anak, dewasa dan orangtua pada website ini, dihalam utama ini seluruh interaksi terjadi dengan menggunakan tampilan yang manarik sehingga membuat user betah untuk melakukan pemilihan sepatu dalam website ecommerce ini, seperti terlihat dalam Gambar 15 


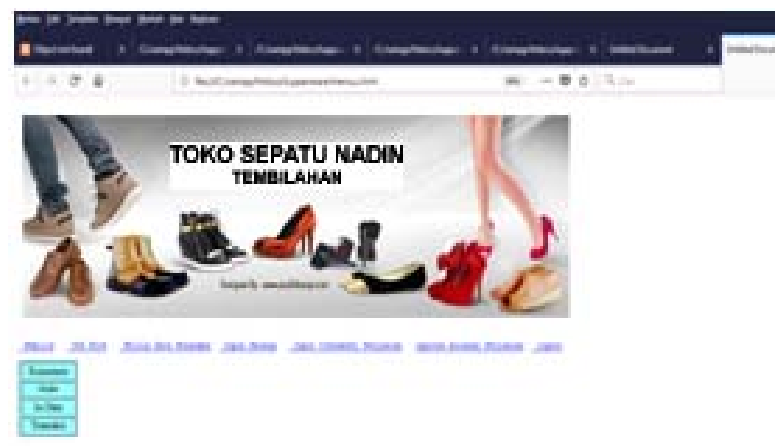

\section{at 0 क}

Gambar 15. Menu Utama e-Commerce

c) Form Cek Stok Barang, form ini menampilkan informasi mengenai status barang apakah masih tersedia atau sudah hanis, sehingga pemilik bisa mengetahui sisa barang yang masih tersebia di toko nadin, tampilan form cek stok barang dapat dilihat pada Gambar 16

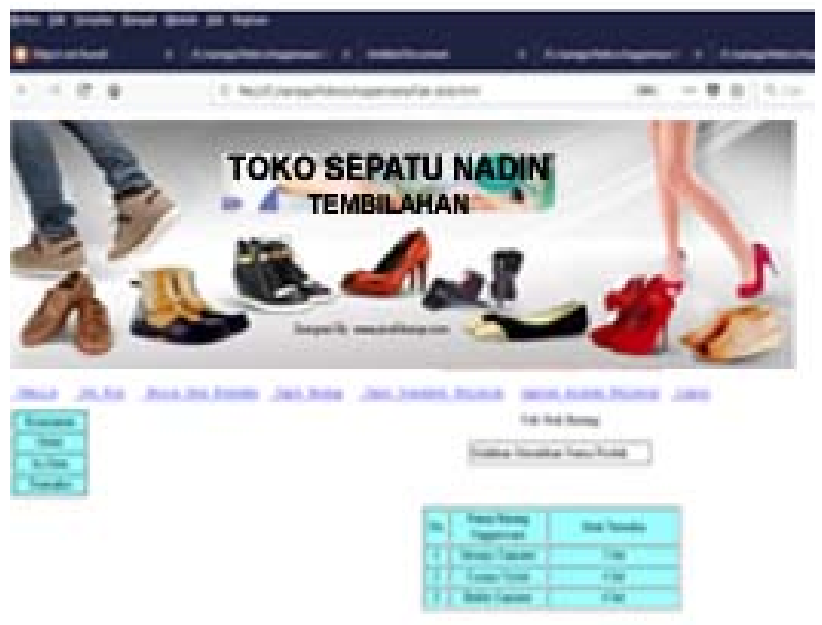

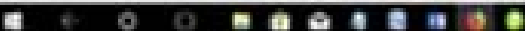

Gambar 16. Menu Cek Stok Barang

d) Menu Kelola Data Konsumen, dalam menu ini disajikan informasi sepatu yang sudah dipesan oleh konsumen, sehingga admin bisa mengelola data tersebut, mengecek apakah stok sepatu masih tersedia, sesuai dengan ukuran yang diminta, warna sepatu yang tersedia, dan sesuai dengan keinginan konsumen, Gambar kelola data konsumen dapat dilihat pada Gambar 17
JUTI-UNISI (Jurnal Tenik Industri UNISI)

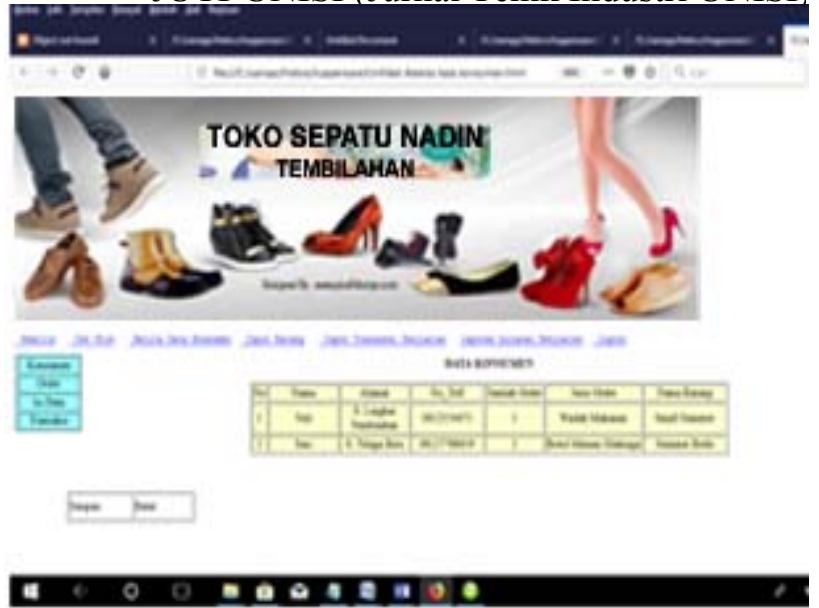

Gambar 17. Menu Kelola Data Konsumen

e) Menu Input Barang, form tampilan input barang merupakan tampilan yang menyajikan informasi proses masukan sepatu, dalam menu ini ditampikan informasi admin akan memasukkan sepatu model baru, sehingga nanti user bisa mengetahui produk baru yang akan bisa dilihat, gambar menu input barang dapat dilihat pada Gambar 18

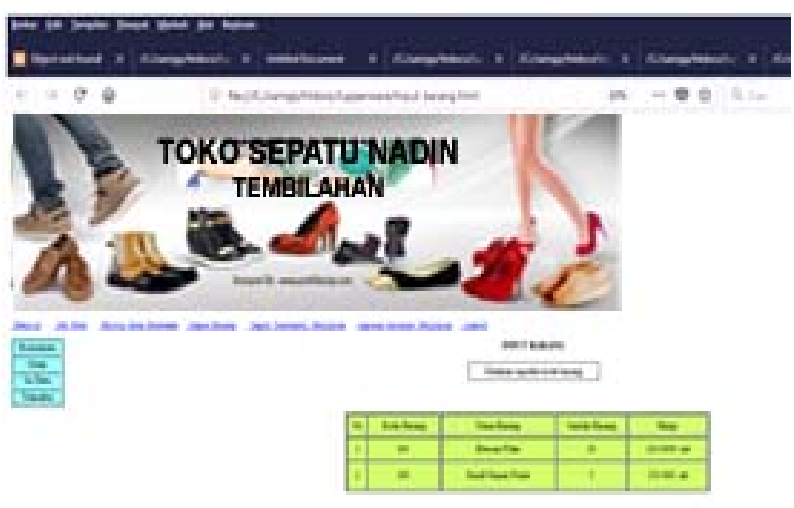

4 o o nas a a

Gambar 18. Menu Input Barang

f) Menu Input Transaksi, dalam menu ini ditampilkan transaksi pembelian sepatu yang dimana user akan diminta untuk mengisi beberapa informasi yang digunakan untuk ditampikan dalam pengiriman barang nantinya, user akan mengetik satu persatu informasi yang tersedia, mulai dari pilihan sepatu, ukuran dan warna sepatu, gambar menu input transaksi dapat dilihat pada Gambar 19 


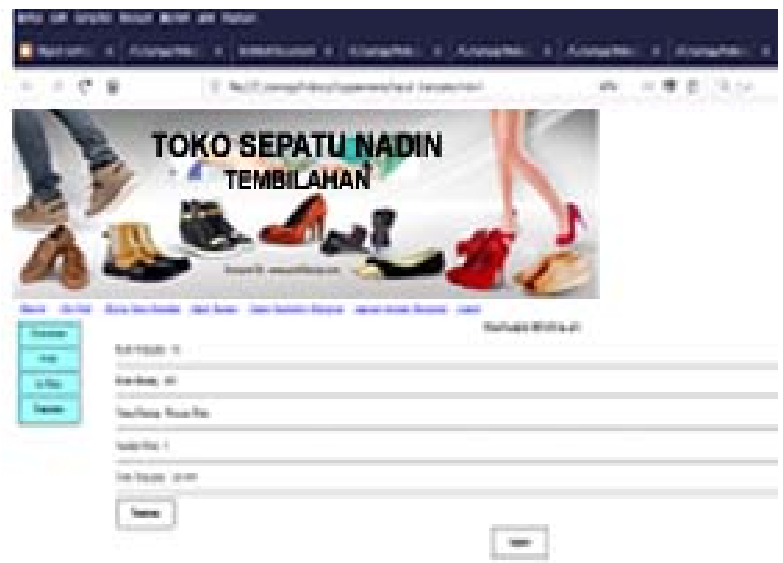

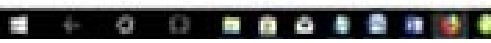

Gambar 19. Menu Input Transaksi

g) Menu Order, halaman yang menampilkan saat konsumen ingin melakukan order / pemesanan sepatu anak kepada pemilik, setelah mengisi form order barang konsumen akan melakukan isi data pribadi konsumen, sehingga pemilik bisa mencarikan data yang diinginkan oleh konsumen, gambar menu order dapat dilihat pada Gambar 20

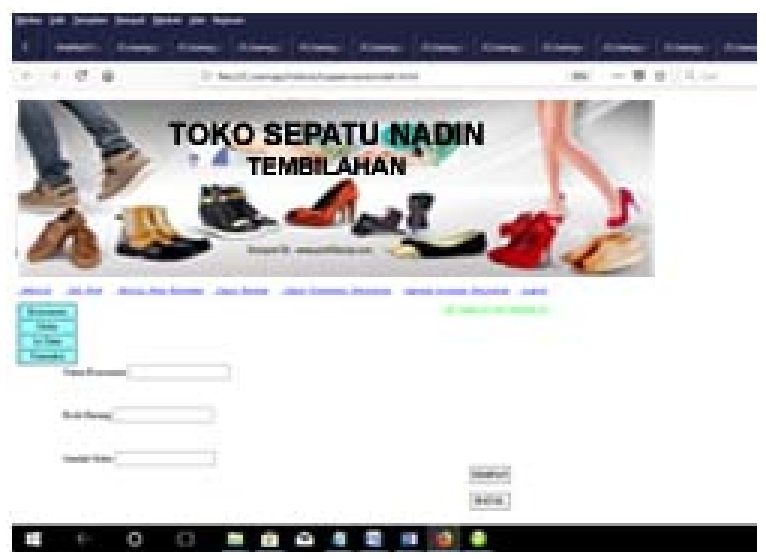

Gambar 20. Menu Order Sepatu

h) Menu Isian Data Konsumen, tampilan isi data konsumen adalah halaman yang menampilkan data-data yang harus diisi oleh konsumen, menu pengisian data konsumen ini dilakukan apabila konsumen melakukan order barang, apabila konsumen tidak memesan sepatu maka konsumen bisa membatalkan pesanan tersebut pemesanan tersebut dengan cara menekan batalkan pemesanan, gambar menu isian data konsumen dapat dilihat pada Gambar 21
JUTI-UNISI (Jurnal Tenik Industri UNISI)

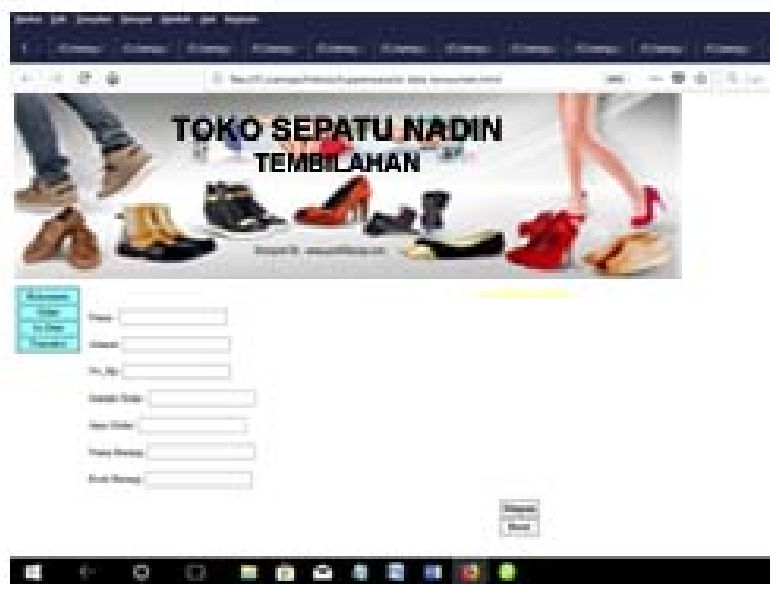

Gambar 21. Menu Order Sepatu

i) Menu Transaksi Barang, tampilan transaksi barang merupakan tampilan yang menyajikan informasi mengenai alamat dan kelengkapan lainnya yang akan diproses, gambar menu transaksi barang dapat dilihat pada Gambar 22

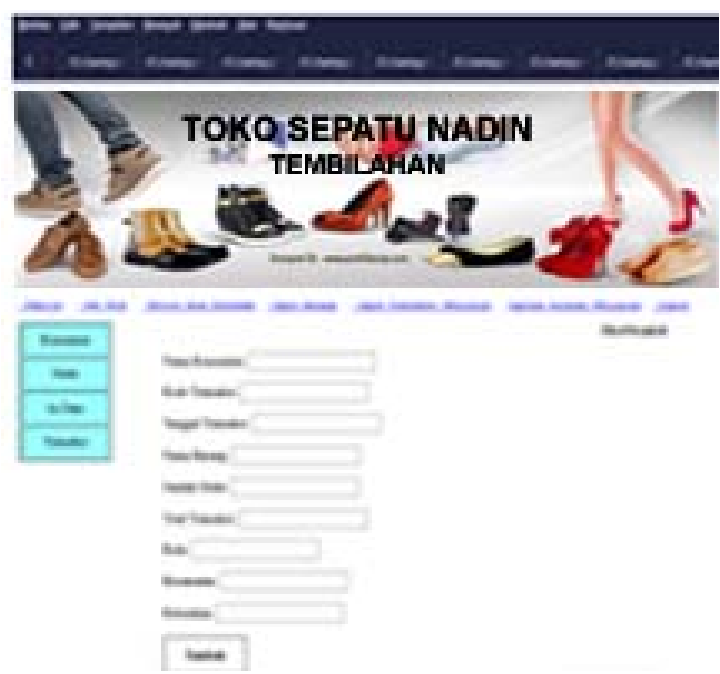

Gambar 22. Menu Transaksi Barang

j) Menu Laporan Barang, menu ini menampilkan laporan barang yang masuk dan laporan keluar seperti Gambar 23

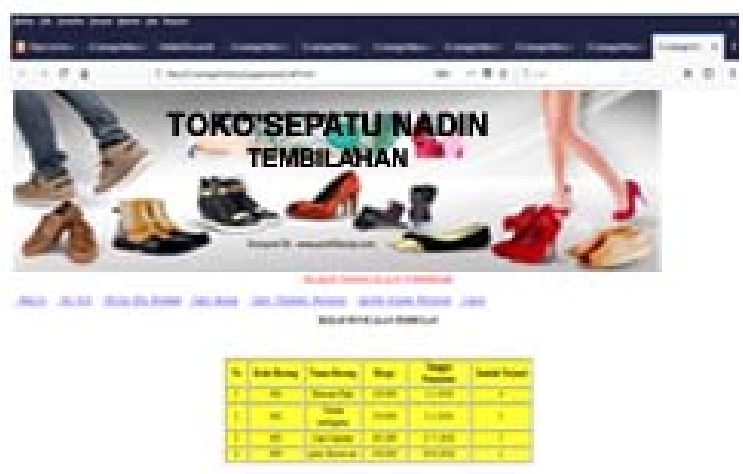

Gambar 23. Menu Laporan Barang 


\subsection{Pengujian Sistem}

Sistem yang baik merupakan sistem yang dilakukan pengujian terlebih dahulu sebelum dilakukan implementasi dilapangan dan dilakukan maintenance, pada tahap ini pengujian dilakukan dengan black box testing. Pengujian black box dilakukan untuk mengetahui segala kemungkinan yang dapat menimbulkan kesalahan sesuai dengan spesifikasi perangkat lunak yang telah ditentukan, sebelum perangkat lunak tersebut diterapkan. Black box testing adalah pengujian yang dilakukan hanya mengamati hasil eksekusi melalui data uji dan memeriksa fungsional dari perangkat lunak. Pengujian black box mengevaluasi hanya dari tampilan luarnya (interfacenya), fungsionalnya. Tanpa mengetahui apa sesungguhnya yang terjadi dalam proses detailnya hanya mengetahui input dan output, gambaran black box testing dapat dilihat pada Tabel 1

Tabel 1. Black Box Testing

\begin{tabular}{|c|c|c|c|}
\hline $\begin{array}{l}\text { Input/ } \\
\text { Event }\end{array}$ & Proses & Output & $\begin{array}{c}\text { Hasil } \\
\text { Pengujian }\end{array}$ \\
\hline $\begin{array}{l}\text { Penekanan } \\
\text { tombol } \\
\text { login }\end{array}$ & $\begin{array}{l}\text { Melakukan } \\
\text { proses login } \\
\text { pengguna } \\
\text { agar dapat } \\
\text { masuk ke } \\
\text { halaman } \\
\text { utama }\end{array}$ & $\begin{array}{l}\text { Pengguna } \\
\text { masuk } \\
\text { kedalam } \\
\text { sistem }\end{array}$ & Sesuai \\
\hline $\begin{array}{l}\text { Penekanan } \\
\text { tombol } \\
\text { order }\end{array}$ & $\begin{array}{l}\text { Melakukan } \\
\text { proses order } \\
\text { atau } \\
\text { pembelian } \\
\text { sepatu sesuai } \\
\text { dengan data }\end{array}$ & $\begin{array}{l}\text { Data order } \\
\text { sepatu } \\
\text { baru } \\
\text { disimpan } \\
\text { pada tabel } \\
\text { order } \\
\text { sepatu }\end{array}$ & Sesuai \\
\hline $\begin{array}{l}\text { Penekanan } \\
\text { menu } \\
\text { laporan }\end{array}$ & $\begin{array}{l}\text { Layar } \\
\text { laporan data } \\
\text { produk dan } \\
\text { penjualan } \\
\text { terbuka }\end{array}$ & $\begin{array}{l}\text { Data } \\
\text { produk } \\
\text { dan } \\
\text { penjualan }\end{array}$ & Selesai \\
\hline
\end{tabular}

Sumber : Data diolah, 2020

Berdasarkan Tabel 1 Black Box Testing didapatkan hasil semua tombol yang ada dalam ecommerce toko sepatu nadin di tembilahan berjalan sesuai yang diharapkan, mulai dari tombol login, order dan report, sesuai dengan keinginan konsumen dan keinginan pemilik toko.

\section{KESIMPULAN}

JUTI-UNISI (Jurnal Tenik Industri UNISI)

Website e-Commerce Toko sepatu Nadin di Tembilahan ini merupakan salah satu cara untuk memudahkan pemilik toko untuk menyebarkan informasi sepatu ke masyarakat luas, apalagi dimasa pandemi Covid-19 ini masyarakat banyak yang berada dirumah dan jarang melakukan interaksi diluar rumah, adapun kesimpulannya

1) Website e-Commerce ini lebih memudahkan dalam proses penjualan pada toko sepatu Nadin di Tembilahan, hal ini ditunjukkan dengan tingginya minat konsumen dalam membeli sepatu di toko Nadin, dengan adanya e-Commerce ini konsumen sangat terbantu,

2) Dalam website ini selain digunakan untuk proses penjualan, e-Commerce toko Nadin dapat melakukan promosi sepatu secara luas ke masyarakat khususnya di wilayah Tembilahan dan juga dapat melakukan promosi untuk luar daerah, hal ini dibuktikan dengan adanya pemesanan dari luar wilayah tembilahan,

3) e-Commerce ini sangat membantu pemilik toko Nadin di tembilahan, dikarenakan dengan adanya e-Commerce ini dapat mudah untuk mengecek stok sepatu, mudah dalam membuat laporan harian dan bulanan, serta mudah dalam pengiriman sepatu.

\section{DAFTAR PUSTAKA}

Ahmad Susanto, N. M. (2016). Rancang Bangun Sistem Informasi Penjualan Batik Berbasis E-Commerce. Evolusi, 5(1), 1-6. Retrieved from http://lppm3.bsi.ac.id/ jurnal/ index.php/evo/article/view/234

Harun Al-Rosyid, Bambang Eka Purnama, I. U. W. (2010). Sistem Informasi Penjualan Buku Berbasis Website Pada Toko Buku Standard Book Seller Pacitan. Indonesian Journal on Networking Security, 7(2), 1-6.

Arista Mahaseptiviana, dkk, (2014). Analisis dan perancangan sistem informasi penjualan air minum pada CV Air Putih. JSIKA Vol 3, No. 22014 / ISSN:2338-137x.

Fendra Sukmana, dkk, 2009. Pembangunan wesite e-Comerse pada Darma Mitra Computer (DMC) Pacitan IJNS-Indonesian Journal On Networking and Security, ISSN:2302- 5700. 